УДК 616-006.36:618.14089:616.381-007274:615.3-6126.

DOI 10.11603/24116-4944.2020.2.11836

${ }^{\odot}$ А. В. Бойчук, В. І. Коптюх, Н. О. Існюк

Тернопільсъкий національний медичний університет ілені І. Я. Горбачевсъкого МОЗ України

\title{
ПОРІВНЯННЯ ЛАПАРОСКОПГЧНОЇ МІОМЕКТОМІї ТА ЕМБОЛІЗАЦІї МАТКОВИХ АРТЕРІЙ У ЖІНОК ІЗ СИМПТОМНОЮ ЛЕЙОМІОМОЮ МАТКИ
}

Мета дослідження - порівняння есективності, безпеки захворюваності та репродуктивних наслідків лікування лейоміоми тіла матки (ЛТМ), виконаних лапароскопічним доступом і технікою емболізації маткових артерій (EMA).

Матеріали та методи. Дослідження проводили на базі гінекологічного відділення КНП «ТКМл № 2». 3a період із 2018 до 2020 р. було проведено 112 лапароскопічних втручань і 52 методики емболізації маткових артерій. Із метою діагностики ЛТМ проводили ультразвукове обстеження органів малого таза, для виконання ЕМА обов'язковою умовою було проведення цитологічного аспірату із порожнини матки. ЕМА проводили в умовах операційної, обладнаної ангіографрічним апаратом.

Результати дослідження та їх обговорення. Середній вік жінок, яким проводили лапароскопічне втручання, перебував у межах 38-42 років, індекс маси тіла - від 25,0 до 31,0, середня кількість видалених вузлів - від 2 до 5. Середній діаметр вузлів коливався в межах від 4 до 6 см. Крововтрата під час операції склала 100-150 мл із застосуванням біполярної діатермії, середня тривалість операції склала 50-60 хв. Післяопераційні ускладнення було відмічено у $30 \%$ жінок.

У групі жінок, яким проводили ЕМА, середній вік перебував у межах 36-45 років. Індекс маси тіла становов 34,2. Середня кількість вузлів, які піддавали емболізації (склерозуванню), складала в основному 2-3 вузли. Крововтрата під час проведення операції емболізації маткових артерій була відсутня. Середня тривалість операції - 50-60 хв. Тривалість перебування в стаціонарі - 3-4 ліжко-дні.

Жінки, які планували вагітність, - це 26,7 \% - 30 пацієнток після лапароскопії, і 38,4 \% - 20 пацієнток після ЕМА. Змогли виконати дітородну фрункцію у першій групі $40 \%-12$ жінок, у другій групі $25 \%$ - 5 жінок.

Висновки. Підсумовуючи результати обох методів лікування лейоміоми матки, ми не отримали даних, які б свідчили про переваги того чи іншого методу. Втім, слід сказати, що ЕМА може бути альтернативою лапароскопії, особливо у групі жінок, які хотіли б виконати репродуктивну фрункцію в плані дітонародження.

Ключові слова: лейоміома матки; емболізація маткових артерій; консервативна міомектомія.

СРАВНЕНИЕ ЛАПАРОСКОПИЧЕСКОЙ МИОМЭКТОМИИ И ЭМБОЛИЗАЦИИ МАТОЧНЫХ АРТЕРИЙ У ЖЕНЩИН С СИМПТОМНОЙ ЛЕЙОМИОМОЙ МАТКИ

Цель исследования - сравнение эфроективности, безопасности заболеваемости и репродуктивных последствий лечения лейомиомы тела матки (ЛТМ), выполненных лапароскопическим доступом и техникой эмболизации маточных артерий (ЭМА).

Материалы и методы. Исследования проводились на базе гинекологического отделения КНП «ТКГБ № 2». За период с 2018 по 2020 г. было проведено 112 лапароскопических вмешательств и 52 методики эмболизации маточных артерий. С целью диагностики ЛТМ проводилось ультразвуковое обследование органов малого таза, для выполнения ЭМА обязательным условием было проведение цитологического аспирата из полости матки. ЭМА проводилось в условиях операционной, оборудованной ангиографическим аппаратом.

Результаты исследования и их обсуждение. Средний возраст женщин, которым проводилось лапароскопическое вмешательство, пребывал в пределах 38-42 лет, индекс массы тела - от 25,0 до 31,0, среднее количество удаленных узлов - от 2 до 5. Средний диаметр узлов пребывал в пределах от 4 до 6 см. Кровопотеря во время операции составила 100-150 мл с применением биполярной диатермии, средняя продолжительность операции составила 50-60 мин. Послеоперационные осложнения были отмечены у $30 \%$ женщин. В группе женщин, которым проводилась ЭМА, средний возраст пребывал в пределах 36-45 лет. Индекс массы тела составил 34,2. Среднее количество узлов, которые подвергались эмболизации (склерозированию), составило в основном 2-3 узла. Кровопотеря во время проведения операции эмболизации маточных артерий отсутствовала. Средняя продолжительность операции - 50-60 мин. Продолжительность пребывания в стационаре - 3-4 дня. Женщины, которые планировали беременность, это 26,7 \% - 30 пациенток после лапароскопии, и 38,4 \% - 20 пациенток после ЭМА. Смогли выполнить детородную срункцию в первой группе $40 \%-12$ женщин, во второй группе $25 \%$ - 5 женщин.

Выводы. Суммируя результаты обоих методов лечения лейомиомы матки, мы не получили данных, свидетельствующих о преимуществах того или иного метода. Подытоживая описанные данные, следует сказать, что ЭМА может быть альтернативой лапароскопии, особенно в группе женщин, которые хотели бы выполнить репродуктивную фрункцию в плане деторождения.

Ключевые слова: лейомиома матки; эмболизация маточных артерий; консервативная миомэктомия.

COMPARISON OF LAPAROSCOPIC MYOMECTOMY AND EMBOLIZATION OF THE UTERINE ARTERIES IN WOMEN WITH SYMPTOMATIC UTERINE LEIOMYOMA

The aim of the study - to compare the efficacy, safety of the disease and the reproductive consequences of treatment of uterine leiomyoma performed by laparoscopic access and uterine artery embolization technique (EMA).

Materials and Methods. The studies were carried out on the basis of the Gynecological Department of the Municipal Noncommercial Enterprise Ternopil Municipal Hospital No. 2. During the period from 2018 to 2020, 112 laparoscopic procedures and 52 
methods of uterine artery embolization were performed. In order to diagnose leiomyoma, an ultrasound examination of the pelvic organs was carried out; to perform UAE, a cytological aspirate from the uterine cavity was a prerequisite. UAE was performed in an operating room equipped with an angiographic apparatus.

Results and Discussion. The average age of women who underwent laparoscopic surgery ranged from 38 to 42 years, body mass index from 25.0 to 31.0, the average number of removed nodes from 2 to 5 . The average diameter of nodes ranged from 4 to $6 \mathrm{~cm}$. Blood loss during the operation was 100-150 ml using bipolar diathermy, the average duration of the operation was 50-60 minutes. Postoperative complications were observed in $30 \%$ of women. In the group of women who underwent EMA, the average age ranged from 36 to 45 years. Body mass index was within 34.2. The average number of nodes that underwent embolization (sclerosis) was mainly 2-3 nodes. There is no blood loss during the uterine artery embolization operation. The average duration of the operation is 50-60 minutes. Duration of hospital stay is 3-4 days. Women who planned a pregnancy are $26.7 \%-30$ women after laparoscopy, and $38.4 \%$ - 20 women after UAE. In group $140 \%-12$ women were able to fulfill the reproductive function, in group $2-25 \%-5$ women.

Conclusions. Thus, summarizing the results of both methods of treating uterine fibroids, we did not receive data indicating the benefits of one or another method of treating uterine fibroids. Summarizing the data described, it should be said that EMA can be an alternative to laparoscopy, especially in a group of women who would like to perform a reproductive function in terms of childbirth.

Key words: uterine leiomyoma; embolization of uterine arteries; conservative myomectomy.

ВСтУп. Золотим стандартом лікування лтМ у жінок репродуктивного віку залишається консервативна міомектомія [3, 4]. Міні-інвазивні хірургічні методи лікування багатьох гінекологічних захворювань мають суттєву перевагу серед пацієнток як із медичної, так і соціальноекономічної точки зору (менший час госпіталізації, швидше відновлення нормальної діяльності) $[2,6]$.

Останнім часом альтернативою лапароскопії для лікування лтМ стає метод емболізації маткових артерій (EMA) у жінок молодого віку з метою виконання репродуктивної функції. Дана операція дозволяє уникнути оперативного втручання і сприяє збереженню не тільки органів для репродукції, але й зменшує відсоток таких ускладнень, як крововтрата, тривалість операції, а також утворення злукового процесу $[1,5]$.

МЕТА ДОСЛІДЖЕННЯ - порівняння ефективності, безпеки захворюваності та репродуктивних наслідків лікування лейоміоми тіла матки, виконаних лапароскопічним доступом і технікою емболізації маткових артерій (ЕMA).

МАТЕРІАЛИ ТА МЕТОДИ. Дослідження проводили на базі гінекологічного відділення КНП «ТКМЛ № 2». За період із 2018 до 2020 р. було проведено 112 лапароскопічних втручань і 52 методики емболізації маткових артерій.

Критеріями відбору для проведення лапароскопічного втручання були: молодий вік жінок (32-44р.), невеликі розміри фріброматозного вузла (до 10 см у діаметрі), розташування вузла субсерозно і частково інтрамурально, відсутність ознак ішемії вузла; найважливішим показанням - можливість жінки вагітніти, виношувати й народжувати дитину. До проведення методики EMA показання були ті ж самі, окрім того, больовий та геморагічний синдром, відсутність стиснення суміжніх органів. Враховували кількість фріброматозних вузлів - від 3 до 5, а також розміри більше 5 см [11, 24].

Протипоказанням до обох методів лікування лтм були тяжкі захворювання серцево-судинної системи, попередня тазова або абдомінальна променева терапія, субмукозні фріброміоми матки із вузлами більше $10 \mathrm{~cm}$, а також кількість фріброматозних вузлів більше п'яти, пухлини придатків матки, онкологічні захворювання, вагітність [7, 8].

3 метою діагностики лтМ проводили ультразвукове обстеження органів малого таза, для виконання EMA обов'язковою умовою був забір цитологічного аспірату із порожнини матки.

ЕMА проводили в умовах операційної, обладнаної ангіограсрічним апаратом. У стегнову артерію вводили емболізаційний препарат. Процедура тривала в середньому 30-50 хв. Усім пацієнткам проводили антибіотикопрофілактику цефралоспоринами другого або третього покоління, а також профрілактику тромбоемболічних ускладнень із використанням низькомолекулярних гепаринів $[9,10]$.

У 3 жінок із лейоміомою матки під час виконання лапароскопічного втручання довелось провести екстирпацію матки у зв'язку з інтралігаментарним розташуванням фріброматозного вузла та вузлів, які ускладнили доступ до судин матки.

У післяопераційному періоді в 4 жінок після EMA спостерігали такі ускладнення, як асептичне запалення некротизованих вузлів, а також їх появу протягом одного місяця післяопераційного періоду [18].

Контрольні УЗД проводили на 3, 6, 12 місяці післяопераційного періоду. Жінкам, які хотіли виконати свою репродуктивну функцію, було дозволено планувати вагітність через 6-12 місяців післяопераційного періоду з урахуванням показників гормонального профілю фраз менструального циклу. Препаратами вибору були гестагени впродовж трьох менструальних циклів $[12,17,18]$.

РЕЗУЛЬТАТИ ДОСЛІДЖЕННЯ ТА ЇХ ОБГОВОРЕНня. Середній вік жінок, яким проводили лапароскопічне втручання, перебував у межах 38-42 років, індекс маси тіла - від 25,0 до 31,0, середня кількість видалених вузлів - від 2 до 5. Із них більшу частину $(71,4$ \%) склали вузли із субсерозним розташуванням, 3 інтралігаментарним розташуванням - 2,6\%, інтрамуральні - 25,8\%. Середній діаметр вузлів перебував у межах від 4 до 6 см. Крововтрата під час операції склала 100-150 мл із застосуванням біполярної діатермії, середня тривалість операції становила 50-60 хв. Післяопераційні ускладнення було відмічено у 30 \% жінок. Це в основному гіпертермія, яку було усунуто призначенням двох антибактеріальних препаратів. У 7 \% жінок спостерігали кров'янисті виділення у незначній кількості, які припинилися після призначення утеротоніків та кровоспинних препаратів. Середня тривалість перебування в стаціонарі склала 4-6 ліжко-днів.

У групі жінок, яким проводили ЕМА, середній вік перебував у межах 36-45 років. Індекс маси тіла становив 
34,2 - дещо вищий порівняно з групою, у якій проводили лапароскопічне втручання. Середня кількість вузлів, які піддавали емболізації (склерозуванню) складала в основному 2-3 вузли. У 57,6 \% жінок фріброматозні вузли були з інтрамурально-субмукозним розташуванням, середній діаметр вузлів перебував у межах 6-7 см. Крововтрата під час проведення операції емболізації маткових артерій була відсутня. Середня тривалість операції - 50-60 хв. Серед післяопераційних ускладнень спостерігали гіпертермію, кровотечі в післяопераційному періоді після емболізації інтрамуральних вузлів, а також появу субмукозних фіброматозних вузлів, що супроводжувалась гіпертермією, больовим синдромом. Тривалість перебування в стаціонарі - 3-4 ліжко-дні.

Жінки, які планували вагітність, - це 26,7 \% - 30 пацієнток після лапароскопії. У цій групі жінок для визначення функціонального стану яєчників проводили гормональні обстеження. Визначали вміст ФСГ, пролактину та прогестерону. Функціональний стан ендометрія оцінювався за даними УЗД, що проводили на 7-14-й день менструального циклу, а функціональний стан яєчників - за кількістю дозрівання фолікулів та їх величиною $[15,16,19]$.

Так, за даними тестів фрункціональної діагностики, у $10 \%$ жінок, які планували вагітність, було визначено зниження рівня прогестерону до 0,5 нг/мм та збільшення пролактину більше 40 нг/мм в овуляторній фразі. Таким жінкам призначали гестагени 10 мг (дусрастон) із 12 до 21 дня менструального циклу протягом трьох менструальних циклів. У 5-6 \% із обстежених жінок призначали агоністи-ГнРГ (золадекс) 3,6 мг 1 раз на місяць впродовж трьох менструальних циклів. Медикаментозне лікування агоністами-ГнРГ спрямоване на зменшення розмірів пухлини матки та покращення фрункції яєчників [22-24]. Таким чином, за даними тестів фрункціональної діагностики матки та яєчників, дітородну фрункцію виконали 12 жінок - 40\%. Після ЕМА 20 пацієнток - 38,4\% планували вагітність. У даній групі жінок проводили обстеження тестів функціональної діагностики стану ендометрія та яєчників за даними УЗД, а також здійснювали визначення показників вмісту гормонів: ФСГ, пролактину та прогестерону. Корекцію гормональних порушень проводили гестагенами в дозі 10 мг впродовж трьох менструальних циклів, агоністами-ГнРГ у дозі 3,6 (золадекс) у тому ж режимі, що й у першій групі. Змогли виконати дітородну функцію у першій групі $40 \%$ - 12 пацієнток, у другій групі $25 \%$ - 5 пацієнток.

\section{СПИСОК ЛІТЕРАТУРИ}

1. Памфамиров Ю. К. Органосберегающий подход в лечении миомы матки / Ю. К. Памфрамиров, В. А. Заболотнов, О. В. Карапетян // Здоровье женщины. - 2013. - № 1. C. $162-164$.

2. Дорогая О. П. Оптимізація методу відновлення репродуктивної фрункції у жінок із субмукозною міомою матки / О. П. Дорогая // Клініч. ендокринол. та ендокр. хірургія. 2014. - № 3 (48). - C. 47-52.

3. Sabry M. Innovative oral treatments of uterine leiomyoma / M. Sabry // Obstet. Gynecol. Int. - 2012. - Vol. 2. - P. 1-10.

4. Кичигин О. В. Факторы риска развития миомы матки и качество жизни пациенток, оперированных по поводу миомы матки / О. В. Кичигин, И. М. Арестова, Ю. В. Занько // Охрана материнства и детства. - 2013. - № 2 (22). - С. 36-41.
Вагітність у жінок першої групи перебігала на фроні загрози переривання вагітності. 3 метою прогресування вагітності та передчасних пологів призначали гестагени в дозі 300 мг на добу до 34-х тижнів вагітності $[12,16]$. Мимовільний викидень був у 33,3 \% - у 4 жінок. Успішна вагітність мала місце у 26 пацієнток, серед них передчасні пологи відбулись у 38,4 \% - 10-ти жінок. Всі діти народились живими, із масою тіла 1800,0-2200,0, пацієнток родорозрішено шляхом операції кесаревого розтину.

У 61,6 \% - 16 жінок відбулись вчасні пологи, у 2 пацієнток - через природні пологові шляхи, у 14 - шляхом операції кесаревого розтину. Діти народились живими із масою 2600,0-3000,0. У жодної жінки не спостерігали розриву матки після міомектомії.

У другій групі дітородну фрункцію бажали здійснити 20 пацієнток. Вагітність настала у $30 \%-6$ жінок та перебігала успішно, завершилась пологами. Вагінальні пологи відбулись у 4 жінок, які доносили вагітність до терміну 37-38 тижнів. У двох жінок вагітність завершилась оперативним родорозродженням шляхом кесаревого розтину в терміні гестації 32 і 34 тижні. Оперативне втручання проводили за показаннями зі сторони матері. Всі діти народились живими.

У групі вагінальних пологів діти народилися із масою 3000,0-3100,0. Діти, народжені передчасно шляхом кесаревого розтину, мали масу 1600,0-2000,0.

висновки. Підсумовуючи результати обох методів лікування лейоміоми матки, ми не отримали даних, які б свідчили про переваги того чи іншого методу. Втім, слід сказати, що ЕМА може бути альтернативою лапароскопії, особливо у групі жінок, які хотіли б виконати репродуктивну фрункцію в плані дітонародження.

ПЕРСПЕКТИВИ ПОДАЛЬШИХ ДОСЛІДЖЕНЬ. Високі вимоги до якості життя у наш час зумовлюють необхідність використання таких технологій, як лапароскопічна міомектомія у жінок із лейоміомою матки в репродуктивному віці, а при неможливості її виконання - ЕМА. Незважаючи на обнадійливі результати в плані виконання функції дітонародження, необхідні подальші дослідження, спрямовані на вдосконалення результатів перебігу клінічної картини, вивчення ускладнень після проведення обох методів лікування, а також прослідковування вагітностей і дітонародження після проведення EMA та лапароскопічної міомектомії.

5. Tropeano $\mathrm{G}$. The timing of natural menopause after uterine fibroid embolization: a prospective cohort study / G. Tropeano, S. Amoroso, C. Stasi // Fertil. Steril. -2011. - Vol. 96. - P. 980-984.

6. Миома матки у больных молодого возраста: клинико-патогенетические особенности / И. С. Сидорова, А. Л. Унанян, Е. А. Коган, Т. Д. Гуриев // Акушерство, гинекология, репродукция. - 2012. - Т. 4 (1). - С. 16-20.

7. Макарчук О. М. Порівняльне оцінювання показників якості життя у пацієнток після оперативного лікування з приводу міоми матки / О. М. Макарчук, Г.М.Гаврилюк // Здоровье женщины. - 2016. - № 8 (114). - С. 94-97.

8. Шарафутдинов Б. М. Оптимизация рентгенэндоваскулярной эмболизации маточных артерий при лечении больных с миомами матки и маточными кровотечениями / 
Б. М. Шарафутдинов, Р. Ф. Акберов, А. З. Шарафеев // Практическая медицина. - 2015. - № 1 (86). - С. 94-97.

9. The management of uterine leiomyomas / G. A. Vilos, C. Allaire, P. Y. Laberge, N. Leyland // J. Obstet. Gynaecol. Can. - 2015. - Vol. 37 (2). - P. 157-178.

10. Comparison of the influence of three fibroid treatment options: supracervical hysterectomy, ulipristal acetate and uterine artery embolization on ovarian reserve - an observationa study / P. Czuczwar, A. Stepniak, P. Milart [et al.] // J. Ovarian. Res. - 2018. - Vol. 11 (1). - P. 45.

11. Запорожченко М. Б. Лейоміома матки - алгоритми лікування жінок репродуктивного віку / М. Б. Запорожченко // Здоровье женщины. - 2015. - № 5. - С. 55-58.

12. Олійник Н. С. Диференційований підхід до використання інноваційних технологій в лікуванні міоми матки : дис. на здобуття наук. ступеня канд. мед. наук : 14.01.01 / Н. С. Олійник ; Запорізька медична академія післядипломної освіти. - Запоріжжя, 2016. - 155 с.

13. Литвиненко О. В. Вплив профрілактичного застосування антикоагулянтів на ефективність емболізації маткових артерій з приводу лейоміоми матки / О. В. Литвиненко // Вісник проблем біології і медицини. - 2015. - Т. 3 (120), № 2. - С. 171-175.

14. Литвиненко А. В. Профрилактика тромбоэмболических осложнений после эмболизации маточных артерий при лейомиоме матки / А. В. Литвиненко // Репродуктивное здоровье. Восточная Европа. - 2015. - № 3 (39). - С. 40-46.

15. Gromova A. Influence of uterine arterial embolization on endometrial hyperplasia progress: Proceedings of the 16th World Congress on Human Reproduction / A. Gromova, O. Litvinenko, O. Gromova. - Berlin, 2015. - P. 45.

16. Кухарчик Ю. В. Течение беременности и родов у женщин с миомой матки / Ю. В. Кухарчик, Л. В. Гутикова, Т. Колесникова // Сб. науч. трудов «Современные перинатальные медицинские технологии в решении проблем демографической безопасности». - Минск : ГУ РНПЦ «Мать и дитя», 2017. - Вып. 10. - С. 59-61.

17. Kongnyuy E. J. Interventions to reduce haemorrhage during myomectomy for the treatment of fibroids (Cochrane Review) / E. J. Kongnyuy, C. Wiysonge // Cochrane Database Sys. Rev. - 2014. - Vol. 8. - CD005355.

18. Uterine reconstruction due to a giant myoma. A case report and literature review / M. N. Gennaro Della Rossa, B. Navarro Santana, M. Rodriguez Verdejo-Arias [et al.] // Open J. Obstet. Gynecol. - 2016. - Vol. 6. - P. 64-72.

19. Presentation and treatment of uterine leiomyoma in adolescence: a systematic review / R. M. Moroni, C. S. Vieira, R. A. Ferriani [et al.] // BMC. Womens Health. -2015. Vol. 22. - P. 15-24.

20. Гутикова В. Миома матки больших размеров: тактика ведения на этапе прегравидарной подготовки, вынашивания беременности и родоразрешения / В. Гутикова, Ю.В.Кухарчик // РМЖ «Мать и дитя». - 2020. - Вып. 3, № 2. - С. 83-87.

21. Increased progesterone receptor expression in uterine leiomyoma: correlation with age, number of leiomyomas, and clinical symptoms / A. Tsigkou, F. M. Reis, M. H. Lee [et al.] // Fertil. Steril. - 2015. - Vol. 104 (1). - P. 170-175.

22. Donnez J. Uterine fibroid management: from the present to the future / J. Donnez, M. M. Dolmans // Hum. Reprod. Update. - 2016. - Vol. 22 (6). - P. 665-686.

23. Munro M. G. Practical aspects of the two FIGO systems for management of abnormal uterine bleeding in the reproductive years / M. G. Munro // Best. Pract. Res. Clin. Obstet. Gynaecol. - 2017. - Vol. 40 - P. 3-22.

24. Ulipristal acetate before high complexity hysteroscopic myomectomy: a retrospective comparative study / S. Ferrero, A. Racca, E. Tafi [et al.] // J. Minim. Invasive Gynecol. - 2016. - Vol. 23 (3). - P. 390-395.

\section{REFERENCES}

1. Pamfamirov, Yu.K., Zabolotnov, V.A., \& Karapetyan, O.V. (2013). Organosberegayushchiy podkhod v lechenii miomy matki [Organ-saving approach in the treatment of uterine fibroids]. Zdorovye zhenshchiny - Women's Health, 1, 162-164 [in Russian].

2. Dorohaya, O.P. (2014). Optymizatsiia metodu vidnovlennia reproduktyvnoi funktsii u zhinok iz submukoznoiu miomoiu matky [Optimization of the method of restoring reproductive function in women with submucosal uterine fibroids]. Klinich. endokrynol. endokr. khir. - Clin. Endocrinol. Endocr. Surg., 3 (48), 47-52 [in Ukrainian].

3. Sabry, M. (2012). Innovative oral treatments of uterine leiomyoma. Obstet. Gynecol. Int., 2, 1-10.

4. Kichigin, O.V., Arestova, I.M., \& Zanko, Yu.V. (2013) Faktory riska razvitiya miomy matki i kachestvo zhizni patsiyentok, operirovannykh po povodu miomy matki [Risk factors for the development of uterine fibroids and the quality of life of patients operated on for uterine fibroids]. Okhrana materinstva i detstva - Protection of Motherhood and Childhood, 2 (22), 36-41 [in Russian].

5. Tropeano, G., Amoroso, S., \& Stasi, C. (2011). The timing of natural menopause after uterine fibroid embolization: a prospective cohort study. Fertil. Steril., 96, 980-984.

6. Sidorova, I.S., Unanyan, A.L., Kogan, Ye.A., \& Guriyev, T.D. (2012). Mioma matki u bolnykh molodogo vozrasta: klinikopatogeneticheskiye osobennosti [Uterine fibroids in young patients: clinical and pathogenetic features]. Akusherstvo, ginekologiya, reproduktsiya - Obstet. Gynecol. Reprod., 4 (1), 16-20 [in Russian].
7. Makarchuk, O.M., \& Havrylyuk, H.M. (2016). Porivnialne otsiniuvannia pokaznykiv yakosti zhyttia u patsiientok pislia operatyvnoho likuvannia z pryvodu miomy matky [Comparative assessment of quality of life in patients after surgical treatment for uterine fibroids]. Zdorove zhenshchyny - Women's Health, 8 (114), 94-97 [in Ukrainian].

8. Sharafutdynov, B.M., Akberov, R.F., \& Sharafeev, A.Z. (2015). Optimizatsiya renthenendovaskulyarnoy embolizatsii matochnykh arteriy pri lechenii bolnykh s miomami matki y matochnymi krovotecheniyami [Optimization of endovascular embolization of uterine arteries in the treatment of patients with uterine fibroids and uterine bleeding]. Praktycheskaya medytsyna - Practical Medicine, 1 (86), 94-97 [in Russian].

9. Vilos, G.A., Allaire, C., Laberge, P.Y., \& Leyland, N. (2015). The management of uterine leiomyomas. J. Obstet. Gynaecol. Can., 37 (2), 157-178.

10. Czuczwar, P., Stepniak, A., Milart, P., Paszkowski, T., \& Wozniak, S. (2018). Comparison of the influence of three fibroid treatment options: supracervical hysterectomy, ulipristal acetate and uterine artery embolization on ovarian reserve - an observational study. J. Ovarian. Res., 11 (1), 45. DOI:10.1186/ s13048-018-0420-1.

11. Zaporozhchenko, M.B. (2015). Leiomioma matky - alhorytmy likuvannia zhinok reproduktyvnoho viku [Leiomyoma of the uterus - algorithms for the treatment of women of reproductive age]. Zdorovye zhenshchiny - Woman's Health, 5, 55-58 [in Ukrainian]. 
12. Oliynyk, N.S. (2016). Dyferentsiiovanyi pidkhid do vykorystannia innovatsiinykh tekhnolohii v likuvanni miomy matky [Differentiated approach to the use of innovative technologies in the treatment of uterine fibroids]. Candidate's thesis. Zaporizhzhia: ZMAPO [in Ukrainian].

13. Lytvynenko, O.V. (2015). Vplyv profilaktychnoho zastosuvannia antykoahuliantiv na efektyvnist embolizatsii matkovykh arterii z pryvodu leiomiomy matky [Influence of prophylactic use of anticoagulants on the efficiency of uterine artery embolization due to uterine leiomyoma]. Visnyk problem biolohii i medytsyny - Bull. Probl. Biol. Med., 3 (120), 2, 171175 [in Ukrainian].

14. Lytvynenko, A.V. (2015). Profilaktika tromboembolicheskikh oslozhneniy posle embolizatsii matochnykh arterii pri leyomiome matki [Prevention of thromboembolic complications after uterine artery embolization in uterine leiomyoma]. Reprod. zdorovye. Vostochn. Evropa - Reprod. Health. East. Eur., 3 (39), 40-46 [in Russian].

15. Gromova, A., Litvinenko, O., \& Gromova, O. (2015). Influence of uterine arterial embolization on endometrial hyperplasia progress: Proceedings of the 16th World Congress on Human Reproduction. Berlin.

16. Kukharchik, Yu.V., Gutikova, L.V., \& Kolesnikova, T.A (2017). Techeniye beremennosti i rodov u zhenshchin s miomoy matki [The course of pregnancy and childbirth in women with uterine fibroids]. Sb. nauch. trudov "Sovremennyye perinatalnyye meditsinskiye tekhnologii v reshenii problem demograficheskoy bezopasnosti" - Collection of scientific works "Modern perinatal medical technologies in solving problems of demographic security". Minsk: GU RNPTs "Mat i ditya" [in Russian].

17. Kongnyuy, E.J., \& Wiysonge, C. (2014). Interventions to reduce haemorrhage during myomectomy for the treatment of fibroids (Cochrane Review). Cochrane Database Sys. Rev., 8, CD005355. DOI:10.1002/14651858.CD005355.
18. Gennaro Della Rossa, M.N., Navarro Santana, B., Rodriguez Verdejo-Arias, M., Valer Cardenas, E., \& Plaza Arranz, J. (2016). Uterine reconstruction due to a giant myoma. A case report and literature review. Open J. Obstet. Gynecol., 6, 64-72. DOI:10.4236/ojog.2016.61008.

19. Moroni, R.M., Vieira, C.S., Ferriani, R.A., dos Reis, R.M., Nogueira, A.A., \& Oliveira Brito, L.G. (2015). Presentation and treatment of uterine leiomyoma in adolescence: a systematic review. BMC. Womens Health, 4, 15. DOI:10.1186/s12905015-0162-9.

20. Gutikova, L.V., \& Kukharchik, Yu.V. (2020). Mioma matki bolshikh razmerov: taktika vedeniya na etape pregravidarnoy podgotovki, vynashivaniya beremennosti i rodorazresheniya [Large uterine fibroids: management tactics at the stage of pregravid preparation, gestation and delivery]. RMZh. Mat $i$ ditya - RMJ. Woman and Child, 2, 83-87. DOI:10.32364/26188430-2020-3-2-83-87 [in Russian].

21. Tsigkou, A., Reis, F.M., Lee, M.H., Jiang, B., Tosti, C., Centini, G., ..., \& Petraglia, F. (2015). Increased progesterone receptor expression in uterine leiomyoma: correlation with age, number of leiomyomas, and clinical symptoms. Fertil. Steril., 104 (1), 170-175.e1.

22. Donnez, J., \& Dolmans, M.M. (2016). Uterine fibroid management: from the present to the future. Hum. Reprod. Update, 22 (6), 665-686.

23. Munro, M.G. (2017). Practical aspects of the two FIGO systems for management of abnormal uterine bleeding in the reproductive years. Best. Pract. Res. Clin. Obstet. Gynaecol., 40, 3-22.

24. Ferrero, S., Racca, A., Tafi, E., Alessandri, F., Venturini, P.L., \& Roberti Maggiore, U.L. (2016). Ulipristal acetate before high complexity hysteroscopic myomectomy: a retrospective comparative study. J. Minim. Invasive Gynecol., 23 (3), 390-395.

Отримано 08.09.20

Прийнято до друку 09.10.20

Електронна адреса для листування: koptyuch@tdmu.edu.ua 